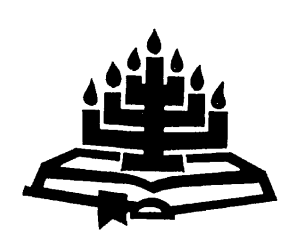

\title{
'n Teksgesentreerde retoriese analise van 1 Korintiërs 4
}

\author{
A.H. Snyman \\ Departement Nuwe Testament \\ Universiteit van die Vrystaat \\ BLOEMFONTEIN \\ E-pos: asnyman44@gmail.com
}

\begin{abstract}
A text-centred rhetorical analysis of 1 Corinthians 4

The traditional approach in rhetorical analyses of Paul's letters is to apply categories derived from the Greek-Roman rhetorical system to make sense of his persuasive strategy. The problem with this approach is that the categories were intended for the production of speeches and not for the analysis of letters. In order to address the problem, scholars have developed alternative approaches to the analysis of his letters - one of them is the so-called text-centred approach.
\end{abstract}

By analysing 1 Corinthians 4 through a text-centred approach, I intend to provide additional evidence that it is unnecessary to force ancient rhetorical categories (from outside) on the chapter to make sense of Paul's persuasive strategy. It can be reconstructed fairly accurately from the text itself, provided that the chapter is studied carefully and systematically.

\section{Opsomming}

\section{'n Teksgesentreerde retoriese analise van 1 Korintiërs 4}

Die tradisionele benadering tot die retoriese analise van Paulus se briewe is die gebruikmaking van kategorieë, ontleen aan die Grieks-Romeinse retoriese sisteem, om sin van sy oorredingstrategie te maak. Die probleem met die benadering is dat hierdie kategorieë vir die maak van toesprake bedoel was en nie vir die analise van briewe nie. Ten einde die probleem te hanteer, het geleerdes alternatiewe benaderings tot die analise van Paulus se briewe ontwikkel, waaronder die sogenaamde teksgesentreerde benadering.

Met die analisering van 1 Korintiërs 4 deur 'n teksgesentreerde benadering, beoog ek om addisionele bewyse te bied dat dit 
onnodig is om antieke retoriese kategorieë van buite op die hoofstuk af te dwing ten einde sin te maak van Paulus se retoriese strategie. Dit kan betreklik akkuraat uit die teks self gerekonstrueer word, mits die hoofstuk sistematies en deeglik bestudeer word.

\section{Inleiding}

In die verlede is die studie van retoriek in Paulus se briewe hoofsaaklik gekenmerk deur die gebruik van die Grieks-Romeinse retoriese sisteem, met sy bekende exordium, propositio, narratio, probatio en peroratio. Die probleem met hierdie benadering is dat kategorieë, ontwerp om 'n toespraak te maak, gebruik word om 'n brief mee te analiseer en sodoende van buite af op die teks afgedwing word. Dit het daartoe gelei dat Nuwe-Testamentici na metodes begin soek het om Paulus se oorredingstrategie vanuit die teks self te konstrueer. Een voorbeeld van so 'n teksgesentreerde benadering tot retoriese analise is die proefskrif van Francois Tolmie: Persuading the Galatians (2005).

In sy eerste hoofstuk verduidelik Tolmie (2005:27-30) die benadering wat hy in sy analise van die Galasiërbrief gevolg het. Nadat hy die retoriese situasie van die brief gerekonstrueer het, formuleer hy wat genoem kan word 'n minimale teoretiese raamwerk om sy analise te rig. Dit is nie as 'n rigiede metodologie bedoel nie, maar as 'n algemene riglyn wat uit die volgende aspekte bestaan:

- Die identifisering van die dominante retoriese strategie in elke gedeelte deur twee vrae te beantwoord: Hoe kan Paulus se primêre retoriese doel in die gedeelte beskryf word? en Hoe probeer hy om dit te bereik?

- Analise van die gedeelte deur op die tipes argumente wat gebruik is, te fokus en waarom hulle effektief is, of 'n beskrywing hoe Paulus argumenteer om sy gehoor te oorreed. Eksegetiese kwessies word bespreek, veral wanneer daar nie duidelikheid is oor die betekenis van 'n spesifieke gedeelte of uitdrukking van retoriese belang nie.

- Identifisering van die retoriese tegnieke wat hy gebruik om die impak van sy kommunikasie te verhoog.

Die doel van hierdie artikel is om addisionele bewyse te bied vir die hipotese dat dit onnodig is om eksterne kategorieë te gebruik om Paulus se oorredingstrategie te verstaan, aangesien dit betreklik akkuraat uit die teks self gerekonstrueer kan word. Vir hierdie doel 
word eerstens verwys na enkele analises van 1 Korintiërs 4 wat op die Grieks-Romeinse retoriese sisteem gebaseer is. Dit word saaklik geëvalueer, waarna bogenoemde voorstel van Tolmie - met sy fokus op die funksionele aspekte van die teks - gebruik word om die proses van oorreding in die hoofstuk te beskryf.

\section{Analises gebaseer op die Grieks-Romeinse retoriese sisteem}

Geleerdes wat hierdie sisteem gebruik, is nie eenstemmig oor die indeling van die Korintiërbrief nie. Volgens Mitchell (1991:1) vorm 1 Korintiërs 4 deel van die sogenaamde proofs, wat strek van 1:1815:571 en ingebed is in die liggaam of deliberatiewe argument van die brief, naamlik 1:10-15:57. Sy onderskei vier gedeeltes in die probatio, te wete $1: 18-4: 21 ; 5: 1-11: 1 ; 11: 2-14: 40$ en 15:1-57. Witherington (1995:94), daarenteen, beskou 1:18-16:12 as die probatio van die brief en verdeel dit in nege argumente. 1 Korintiërs 4 is deel van die eerste argument, wat strek van 1:18-4:21. Die primêre funksie van die probatio is om argumente te bied ter ondersteuning van die redenaar se saak, soos gestel in die propositio. Mitchell en Witherington stem saam dat die propositio van die brief in 1:10 te vind is: "Ek doen 'n beroep op julle almal, broers, ... om eensgesind te wees. Daar moet geen verdeeldheid onder julle wees nie."

Die Grieks-Romeinse retoriese sisteem is nie net vir die indeling van die brief as geheel gebruik nie, maar ook vir die indeling van die eerste vier hoofstukke, en hoofstuk vier in die besonder. Malan (1993:100-102) verdeel die eerste vier hoofstukke soos volg:

- Exordium: 1:10-17.

- Narratio: 1:18-2:16.

- Argumentatio, met sy positiewe probatio in 3:1-17 en die negatiewe refutatio in 4:1-13.

- Peroratio, wat bestaan uit die recapitulatio in 3:18-23 en die affectus in 4:14-21.

Intern bestaan 1 Korintiërs 4 dus uit 'n refutatio ( $4: 1-13)$ en 'n peroratio (4:14-21), waarin Paulus die Korintiërs se twyfel oor sy gesag en lering hanteer. 
Die benadering word deur 'n paar punte geknel. Die belangrikste is dat daar nie 'n eenvormige retoriese sisteem in die Grieks-Romeinse periode bestaan het nie, al is daar oorvleueling tussen die verskillende retoriese modelle (Anderson, 1999:35). Die retoriese teorie het oor die jare heen op verskillende maniere ontwikkel, met die gevolg dat bogenoemde kategorieë nie konsekwent gebruik is nie. $\mathrm{Na}$ watter klassieke teoretikus word dus verwys wanneer die kategorieë gebruik word?

Die tweede knelpunt het te doen met die verskille tussen geleerdes wat dieselfde kategorieë op die brief toepas. Wat die indeling van die brief betref, laat Mitchell en Witherington albei die probatio by $1: 18$ begin, maar verskil wat betref die aantal argumente in die probatio, asook oor die einde van die probatio. Dit het implikasies vir die plek en funksie van hoofstuk 4 in die brief. Hulle verskil ook oor die afbakening van die peroratio. Vir Mitchell (1991:291-293) is 15:58 die peroratio, terwyl Witherington (1995:76) dit afbaken tot 16:13-18. Malan (1993:101) daarenteen, is van oordeel dat sowel die probatio (3:1-17) as die refutatio $(4: 1-13)$ 'n peroratio aan die einde het, naamlik 3:18-23 en 4:14-21 onderskeidelik. Porter (1997: 554) merk tereg op dat die gebruik van dieselfde retoriese sisteem met soveel verskillende resultate 'n vraagteken oor die teoretiese regverdiging van die benadering plaas. Dit is een van die belangrikste redes waarom Nuwe-Testamentici na ander maniere begin soek het om die proses van oorreding in die brief te beskryf.

Derdens dek die propositio in 1:10 nie die hele brief soos Mitchell en Witherington beweer en die klassieke sisteem vereis nie. Die probleem van verdeeldheid kom slegs in 1 Korintiërs 1-4 aan die orde. Die knelpunt bied 'n groot uitdaging vir die voorstanders van die benadering. In plaas daarvan om oor die afbakening van die kategorieë te begin argumenteer en sodoende by te dra tot die afdwinging van 'n eksterne retoriese model op die teks, lyk dit meer verantwoord om Paulus se oorredingstrategie vanuit die teks self te identifiseer en te beskryf.

\section{3. 'n Teksgesentreerde analise van 1 Korintiërs 4}

\subsection{Inleiding}

Twee sake verdien aandag voordat die proses van oorreding in besonderhede bespreek word, naamlik die retoriese konteks waarin Paulus 1 Korintiërs geskryf het, asook Paulus se retoriese strategie. 


\subsection{1 'n Rekonstruksie van die retoriese konteks waarin Paulus 1 Korintiërs geskryf het}

"Die mense van Chloë" (1:11) het hom mondelings ingelig oor die situasie in Korinte en waarskynlik ook die brief aan hom oorhandig waarna in 7:1 verwys word (Schüssler Fiorenza, 1987:395). Paulus het in die eerste plek hieruit van die onderlinge twis in die gemeente te wete gekom. Dit het ernstige implikasies vir sy apostoliese gesag gehad. Die twis het op partydigheid tussen die gemeentelede uitgeloop, met die belangrikste geskilpunt die betekenis daarvan om pneumatikos te wees (Schüssler Fiorenza, 1987:397-398; Witherington, 1995:74 \& Pogoloff, 1992:237). Die Korintiërs het die spreek in tale as die basiese kriterium van spiritualiteit beskou, terwyl juis hulle belangstelling in sophia en gnōsis, hulle besondere wysheid en meerdere kennis gegee het. Dit het noodwendig tot kauchēsis gelei, wat radikaal teen Paulus en sy boodskap ingedruis het en dus reggestel moes word.

In die tweede plek is die brief geskryf in reaksie op sekere praktiese aangeleenthede wat in die brief geopper is (7:1). Dit sluit in die huwelik en seksualiteit (5-7), aanbidding en die gawes van die Gees (11:2-14:40), asook die opstanding (15:12-57). 'n Addisionele doel van die brief is om leiding oor hierdie hoofsaaklik etiese kwessies te gee.

In die brief probeer Paulus dus om sy lesers te oorreed om sy gesag as apostel (insluitend die waarheid van sy kruisevangelie en die ware aard van die apostelskap) te erken, hulle selfverheffing te laat vaar, en so hulle partydigheid te oorkom. Hy gee ook leiding oor 'n paar ander kwessies waaroor hulle navraag gedoen het. Deurgaans gebruik hy effektiewe argumente en oorredingstegnieke soos hieronder geïllustreer sal word.

\subsubsection{Paulus se retoriese strategie}

Die eerste vier hoofstukke, asook die argument in 1 Korintiërs 4, word in hierdie artikel ingedeel aan die hand van retoriese oorwegings aan die teks self ontleen. In 1:18-2:16 verduidelik Paulus die evangelie aan die hand van die kontras tussen goddelike en menslike wysheid. In 3:1-4 verander hy sy retoriese strategie van 'n verduideliking na 'n teregwysing. 1 Korintiërs 3 word met 'n doksologie afgesluit (3:21-23), wat gewoonlik 'n duidelike retoriese merker in Paulus se briewe is (vgl. Rom. 8:31-39 \& 11:33-36). 1 Korintiërs 4 benader die verdeeldheid in die gemeente vanuit 'n ander hoek, naamlik die gesindheid van die Korintiërs teenoor Paulus self. Naas 
die doksologie in 3:21-23, word die skeiding tussen 3:23 en 4:1 ook deur 'n nuwe analogie gemerk, naamlik dié van 'n huishouding ten einde sy bediening te verdedig (4:1-5) deur asundeton in $4: 1$ en deur die verandering van die tweedepersoon meervoud in 3:21-23 na die eerstepersoon meervoud in 4:1. Nadat hy in 4:6-13 die ware aard van apostelskap breedvoerig verduidelik het, sluit Paulus die hoofstuk met 'n vermaning in 4:14-21 af, terwyl 1 Korintiërs 5 oor ander sake handel wat onder sy aandag gekom het. As afsluiting van die hele gedeelte oor partydigheid, vorm 1 Korintiërs 4 dus 'n onderskeidende fase in Paulus se argument.

Hoe kan die oorhoofse retoriese strategie in hierdie fase beskryf word? In die lig van die vorige paragraaf, kan dit saaklik formuleer word as 'n finale poging om die Korintiërs te oorreed om hulle partydigheid te laat vaar deur die bediening en ware apostelskap reg te verstaan.

Hierdie fase kan in drie gedeeltes verdeel en ook op grond van retoriese oorwegings afgebaken word, naamlik 4:1-5, 4:6-13 en 4:14-21. Redes vir die begin van die eerste gedeelte is, soos genoem, die analogie met 'n huishouding en die verandering van die tweede- na die eerstepersoon meervoud. Die ondersteunende retoriese strategie kan dus beskryf word as: "Verdedig sy bediening aan die hand van die analogie met 'n huishouding".

In 4:6 begin 'n nuwe gedeelte, wat deur die emfatiese (uitdruklike)

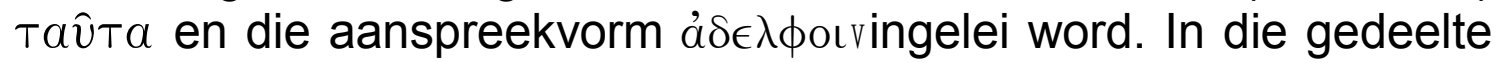
4:6-13 gaan Paulus breedvoerig op die ware aard van apostelskap in. Sy strategie hier kan dus lees: "Verduidelik ware apostelskap deur 'n reeks kragtige oorredingsmiddele te gebruik".

Die derde gedeelte word deur die werkwoord $\gamma \rho a ́ \phi \omega$ en 'n nuwe analogie ingelei, naamlik dié van 'n vader teenoor sy kinders. Tegelyk verander sy retoriese strategie van 'n verduideliking na 'n vermaning, en berei hy hulle voor op sy besoek saam met Timoteus. Die ondersteunende retoriese strategie in 4:14-21 kan saaklik beskryf word as: "Vermaan die Korintiërs om hom as hulle Vader te volg".

Saamgevat: Die oorhoofse retoriese strategie in hierdie fase word deur drie strategieë ondersteun, elkeen op grond van interne retoriese oorwegings afgebaken en bedoel om die partydigheid in die gemeente te beëindig. 


\subsection{Analise}

\subsubsection{Korintiërs 4:1-5: verdedig sy bediening aan die hand van die analogie met 'n huishouding}

Naas die twee analogieë in 3:5-9b en 3:9c-17, gebruik Paulus 'n derde analogie in 4:1-5. Hy verander sy retoriese strategie van 'n waarskuwing na 'n verdediging wanneer hy skryf:

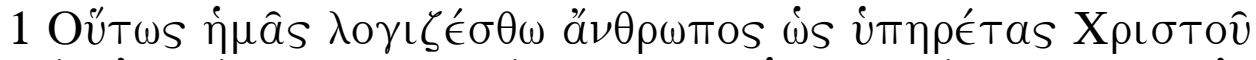

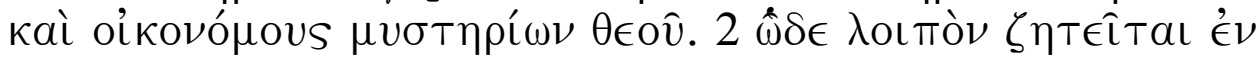

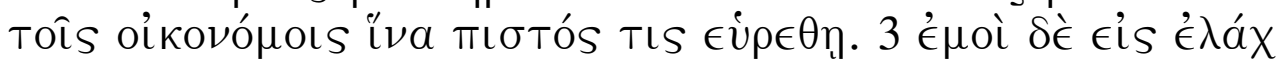

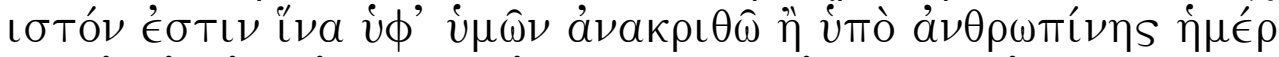

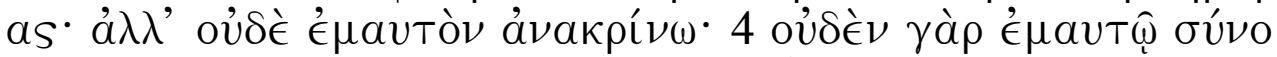

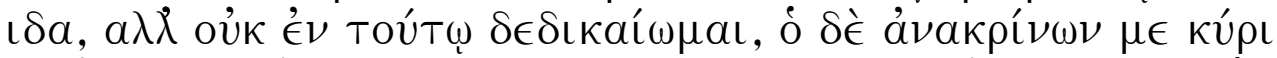

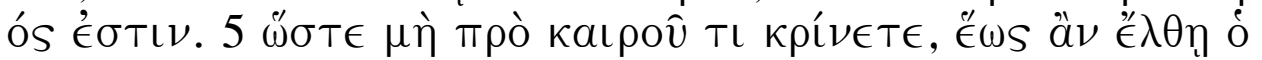

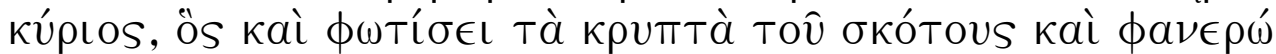

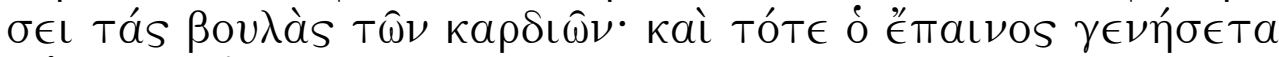

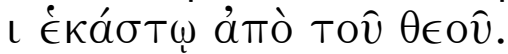

Die Korintiërs het nie net die taak van kerkleiers en die aard van die kerk verkeerd verstaan nie, daar was ook fout met hulle gesindheid teenoor Paulus en sy bediening. In 'n poging om sy bediening te verdedig en sy gesag te handhaaf, gebruik hy twee soorte argumente: een gebaseer op analogie en die ander op God se betrokkenheid.

'n Argument wat op analogie gebaseer is, is 'n effektiewe oorredingsmiddel, soos Tolmie (2005:145-152) in sy bespreking van Galasiërs 4:1-7 uitwys. 'n Analogie is op die punt af en maklik om te verstaan: 'n situasie bekend aan die hoorders word kortliks beskryf en dan op die saak onder bespreking toegepas. Die effektiwiteit daarvan berus veral op die feit dat dit oorspronklik is en die hoorders help om 'n saak vanuit 'n bepaalde gesigspunt te beskou (Cornelius, 1998:560). Die analogie word eers op Paulus, Apollos en Sefas toegepas, en vanaf 4:3 op Paulus alleen. Dit word met oíkovó $\mu$ o in 4:1 en 4:2 ingelei, bevestig deur kúpıos in 4:4 en afgesluit met 'n emfatiese $\dddot{\sigma} \sigma \tau \epsilon$ plus indikatief $(\mu \eta ; \ldots \kappa \rho(\nu \in T \epsilon)$ in 4:5. Die analogie dek dus die hele gedeelte. Die term oikovópos beteken "one who has the authority and responsibility for something - one who is in charge of, one who is responsible for, administrator, manager" (Louw \& Nida, 1988:477). In 4:2 kom Paulus by die kern van die saak: 'n oíkovópos moet betroubaar wees in die gesag en verantwoordelikheid wat aan hom toevertrou is. Die analogie met ' $n$ huishouding word oortuigend op veral Paulus toegepas: hy is in God se 
diens, nie in diens van die Korintiërs nie. God self sal hom beoordeel aan die hand van slegs een kriterium, naamlik betroubaarheid.

Die tweede soort argument wat Paulus in hierdie gedeelte gebruik, is een wat op God se betrokkenheid gebaseer is. Aan die einde van 4:4 en 4:5 (dus altwee in beklemtoonde posisies) skryf hy:

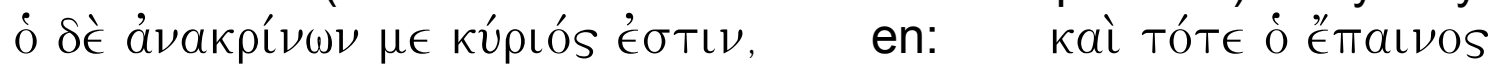

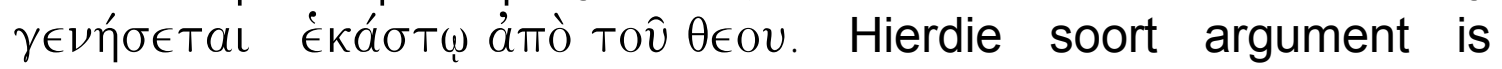
effektief, omdat dit Paulus se bediening legitimeer en bestempel as iets wat nie sy oorsprong in mense of menslike wysheid het nie. Deur God aangestel, is Paulus aan Hom alleen verantwoordelik. Wie dus voor die tyd oordeel, oortree op 'n terrein wat slegs aan God behoort. Hoe die Korintiërs oor hom en sy bediening oordeel, is heeltemal voortydig en irrelevant.

Die volgende retoriese tegnieke ondersteun Paulus se argumentasie in 4:1-5:

- Die plasing van $\dot{\eta} \mu \hat{\alpha} s$ voor die werkwoord in 4:1, en $\epsilon$ foì $\delta \epsilon$ aan die begin van 4:3 beklemtoon die groep mense onder bespreking - waarvan Paulus 'n tipiese voorbeeld is (Lenski, 1963:163-165).

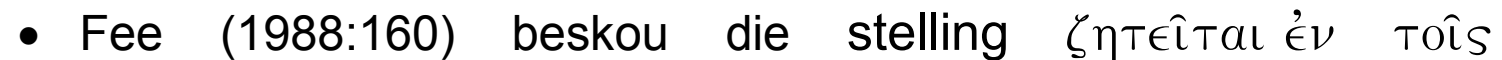

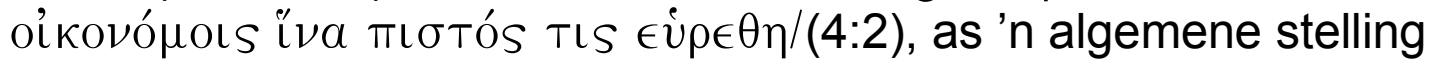
of 'n spreuk (maxim). Indien korrek, versterk dit die opvatting van betroubaarheid, aangesien 'n spreuk aan almal bekend is en deur hulle aanvaar word. Dit hoef nie eers beredeneer te word nie.

- Duplisering van dieselfde gedagte in 4:5 (ôs kaì $\phi \omega t i ́ \sigma \in \mathrm{L}$

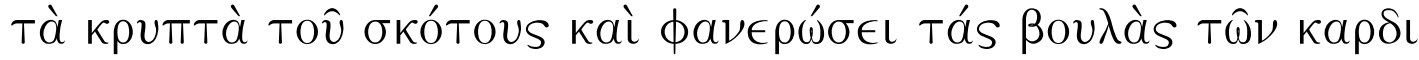
$\hat{\omega} \nu)$ as 'n semitiese parallelisme, beklemtoon dat niks vir God verberg kan word nie (Conzelmann, 1975:84 \& Fee, 1988:164). Die feit dat albei frases dieselfde struktuur het, verhoog die effektiwiteit daarvan en staan tegnies bekend as parison (Nida et al., 1983: 180).

- Die plasing van die woord Tóte aan die begin en die voorsetselfrase, ámò Tố $\theta \in O v$, aan die einde van 4:5 beklemtoon dat God dán (by die wederkoms) sal oordeel en dat sý oordeel - in onderskeiding van alle menslike oordeel - die enigste is wat saak maak (Barrett, 1992:104 \& Wolff, 2000:82-83).

Samevatting: In 'n poging om sy bediening te verdedig en die Korintiërs se gesindheid teenoor hom te verander, maak Paulus in 4:1-5 gebruik van argumente gebaseer op analogie en goddelike betrokkenheid. Retoriese tegnieke wat die poging ondersteun, sluit in die 
gebruik van 'n spreuk, die herhaling van woorde en frases, die plasing van woorde in beklemtoonde posisies en parison.

\subsubsection{Korintiërs 4:6-13: verduidelik ware apostelskap deur 'n reeks kragtige retoriese middele te gebruik}

In die gedeelte pas Paulus al die analogieë op die situasie in Korinte toe, en begin deur hulle met hulle hoogmoed te konfronteer. Hy skryf:

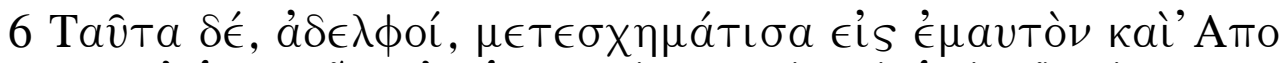

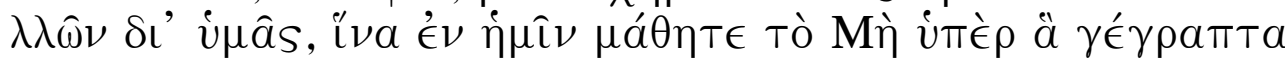

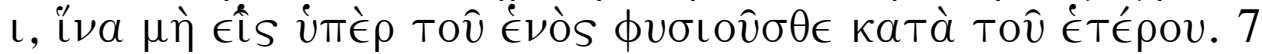

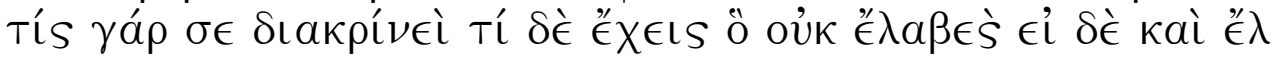

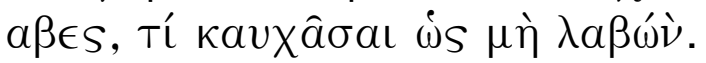

In die twee aanvangsverse van hierdie gedeelte is die volgende sake van retoriese belang. Die eerste is die voorsetselfrase, $\dot{\epsilon} \nu \dot{\eta} \mu \hat{\imath} \nu$, in 4:6 waardeur Paulus homself en Apollos voorhou as mense by wie die Korintiërs iets kan leer. Só 'n argument gebaseer op 'n voorbeeld is effektief, aangesien dit op konkrete en sigbare wyse 'n (gewoonlik) abstrakte waarheid illustreer. Indien die gehoor die voorbeeld ken, help dit hulle om die saak onder bespreking beter te verstaan. Sodoende word die oorredingskrag van die bespreking versterk.

Maar wát is dit wat die Korintiërs by Paulus en Apollos kon leer? Dit bring ons by die tweede saak van retoriese belang. Hieroor bestaan daar 'n meningsverskil: die vraag is na watter geskrif Paulus verwys

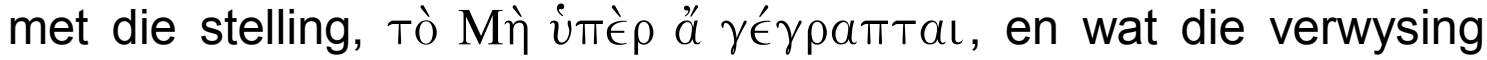
beteken. Barrett (1992:106-107) bespreek drie moontlikhede. Die eerste moontlikheid is dat dit na 'n gedeelte uit die Ou Testament verwys, omdat die bepaalde lidwoord tovgewoonlik sodanige verwysing inlei. Tweedens, kan dit na 'n algemene spreuk verwys wat die Korintiërs in hulle partydigheid gebruik en op dieselfde vlak as die Skrif hanteer het. In die derde plek kan dit nie na 'n onbekende gedeelte in die $\mathrm{Ou}$ Testament verwys nie, maar spesifiek na dié gedeeltes waarna 1 Korintiërs 1-3 verwys. Barrett (1992:107), Groenewald (1967:59) en Fee (1988:169) verkies laasgenoemde moontlikheid, waar al die verwysings gebruik is om die Korintiërs te laat afsien van menslike wysheid en roem, wat 'n grondoorsaak van hulle partydigheid was.

Hoewel daar nooit volkome duidelikheid en eenstemmigheid sal wees nie, blyk laasgenoemde voorstel die beste te wees, en wel om

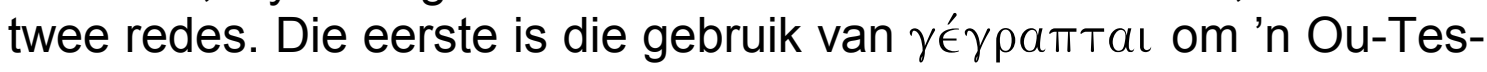


tamentiese sitaat aan te dui, byvoorbeeld in $1: 19 ; 1: 31 ; 2: 9$ en $3: 19$ 20 (waar gewoonlik na menslike wysheid in teenstelling met die van die kruis verwys word). Tweedens word hierdie voorstel deur die retoriese konteks van die brief gesteun, by name die Korintiërs se roem op hulle soort spiritualiteit wat direk hierna in 4:7 hanteer word. Indien die interpretasie korrek is, het die verwysing ' $n$ belangrike retoriese funksie. Tolmie (2005:97, 165-176 \& 194-195) noem sulke verwysings argumente gebaseer op die gesag van die Skrif. Deur sy argument te baseer op 'n skriftelike tradisie wat aan die meeste van sy hoorders bekend is en deur hulle as gesaghebbend aanvaar word, kan Paulus hulle oorreed om nie op die wysheid van hulle leermeesters te roem nie en daardeur hulle onderlinge twis te laat vaar.

Die derde oorredingsmiddel in die twee verse is die gebruik van retoriese vrae in 4:7, en wel in die tweedepersoon enkelvoud - die enigste keer wat Paulus dit in hierdie gedeelte doen. Die vrae verskaf redes waarom diegene wat hulleself verhef, verkeerd is. Retoriese vrae is volgens Cronjé (1993:38-39, in navolging van Demetrius in sy Peri Hermeneias) as van die kragtigste oorredingsmiddels beskou, omdat hulle die hoorder vasvang en by die argument betrek. Deur retoriese vrae in plaas van gewone stellings te gebruik, slaag Paulus daarin om die selfverheffing van die Korintiërs op 'n kragtige wyse te hanteer.

'n Oorredingsmiddel met dieselfde effek, is die opeenvolging van die drie vrae in 4:7 sonder verskaffing van enige antwoorde. Die implisiete antwoorde op die eerste twee vrae is natuurlik negatief, terwyl die laaste vraag die "niks" van die tweede een veronderstel, en as 'n vraagstelling verstaan moet word: "As dit dan so is dat julle dit ontvang het, waarom roem julle asof julle dit nie (as 'n gawe) ontvang het nie?" (Conzelmann, 1975:85, 87). Hierdie soort vraag verwag geen antwoord nie en in die konteks is dit hier as 'n teregwysing bedoel. Deur die drie kort vrae aaneen te ryg sonder om enige antwoorde te verwag, gebruik Paulus kragtige middels om die Korintiërs te oorreed om hulle selfverheffing te laat vaar, naamlik deur te erken dat hulle alles wat hulle het, van God ontvang het. Wanneer hulle dit doen, is een van die belangrikste redes vir hulle onderlinge twis uit die weg geruim.

Met 'n paar kort opmerkings gaan Paulus voort om die Korintiërs te beskryf soos hulle hulself sien. Hy kontrasteer dit met die posisie van ware apostels. 


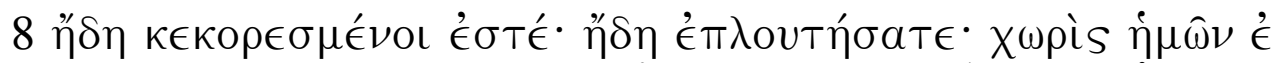

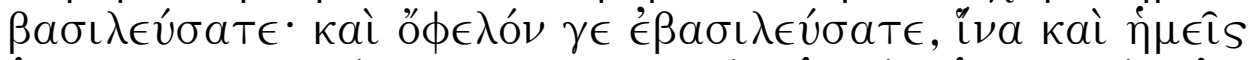

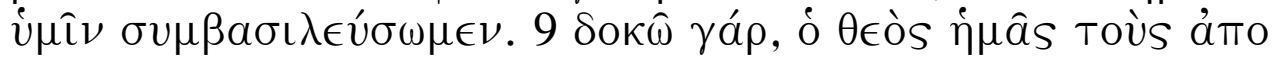

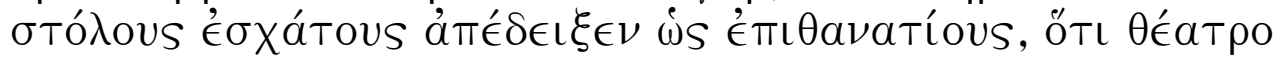

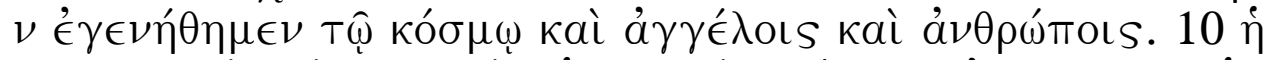

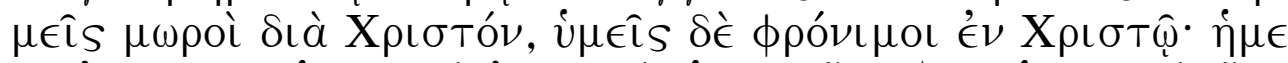

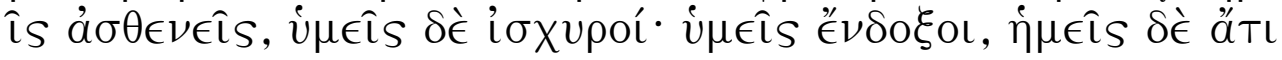
Hol.

Hierdie paar verse is met ironie gelaai. Paulus het dus presies die teenoorgestelde van wat hy sê, bedoel (Nida et al., 1983:185): hy sê dat die Korintiërs reeds versadig is, ryk geword het en heers, maar hy bedoel presies die teenoorgestelde. Dieselfde geld vir die kontraste in 4:10. Die funksie hiervan is om weereens die vermaning van die Korintiërs se selfverheffing - hierdie keer deur ware apostelskap te kontrasteer met hoe die Korintiërs hulleself beskou.

Die ironie word deur 'n aantal kragtige retoriese tegnieke aan die begin van 4:8 en in 4:10 (sien hieronder) versterk. Die ironiese versugting om saam met die Korintiërs te heers (einde van 4:8), berei die weg vir 4:9 en 10 voor, wat weer deur twee belangrike oorredingsmiddels gekenmerk word, naamlik beeldspraak en antiteses. Om die posisie van alle ware apostels te beskryf, gebruik Paulus die beeld van 'n arena waar heersers op verhewe plekke sit, terwyl die apostels die laagste plekke inneem en aan die skare vertoon word voordat hulle moet sterwe. Op hierdie wyse het hulle 'n skouspel geword vir die menigte wat in die arena byeengekom het. Die funksie van die beeld is om die teenstelling tussen die selfverheffing van die Korintiërs en die vernedering van die apostels visueel voor te stel: laasgenoemde deel nie in die kroon van 'n koning nie, maar in die dood van 'n veroordeelde - in navolging van Christus (Groenewald, 1967:61; Fee, 1988:175; Thiselton, 2000:359-360). Dit geld van alle ware apostels, soos uit die inklusiewe "ons" in 4:9 en 10 blyk. Met hierdie beeld word die ironie versterk wat 4:8-10 kenmerk, terwyl die vernedering van die apostels verder in die laaste deel van die 1 Korintiërs 4:11-13 uitgewerk word.

Die ironie bereik sy hoogtepunt met die antiteses in 4:10 (teenoor Groenewald, 1967:61, wat reken dat Paulus se toon in hierdie vers versag). Hiermee stel Paulus die Korintiërs finaal teenoor homself en alle ware apostels, en probeer hy om hulle op 'n kragtige wyse te oorreed om hulleself in die regte lig te sien: hulle is nie die verstandiges en aristokrasie in Korinte nie, al beskou hulle hulself so. Hulle begryp nie die theologia crucis as die enigste kriterium vir ware apostelskap nie (Conzelmann, 1975:89). 
Om die gedeelte oor die ware aard van apostelskap af te rond, skryf Paulus:

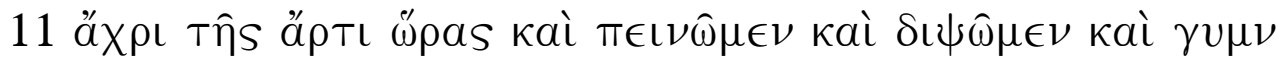

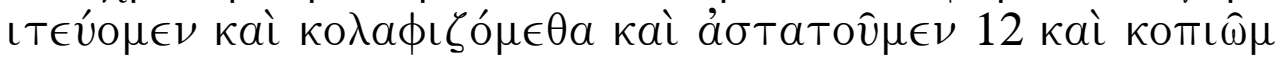

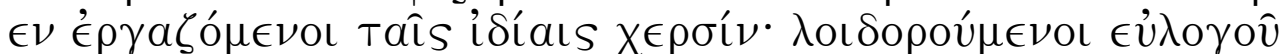

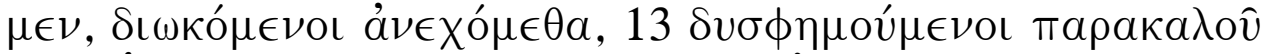

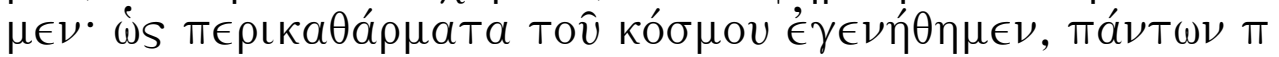
$\epsilon \rho i ́ \psi \eta \mu \alpha, \ddot{\epsilon} \omega s$ äp

Die ironie, wat 4:8-10 gekenmerk het, maak hier plek vir harde feite (teenoor Lenski, 1963:187, wat reken dat die ironie steeds voortgaan). In hierdie gedeelte gaan dit oor die beproewings van hulle wat die boodskap van die kruis verkondig. Die reeks feite word in die vorm van 'n lys beproewings ( $\pi \epsilon \rho i ́ \sigma \tau a ̈ \sigma ı s)$ verskaf. Sulke lyste kom onder andere voor in 2 Korintiërs 4:8-9; 6:4-5; en 11:23-29 en was algemeen gebruiklik in die antieke tyd (Fitzgerald, 1988). Die Korintiërs was waarskynlik bekend met die werke van die Stoïsynse filosowe. Paulus pas dit nou aan vir sy doel, naamlik om die Korintiërs se hoogmoed en verkeerde beskouing oor wysheid reg te stel (Fitzgerald, 1988:204). 'n Wyse persoon se lewe word, volgens die Stoa, deur ontberings gekenmerk. Om met jou hande te werk is die kenmerk van 'n wyse persoon, nie om as 'n koning te regeer nie. Volgens Fitzgerald (1988:207) berus Paulus se retoriek in hierdie gedeelte op die Stoïsynse siening van wysheid, wat radikaal van die Korintiërs se aansprake in hierdie verband verskil. Die funksie van

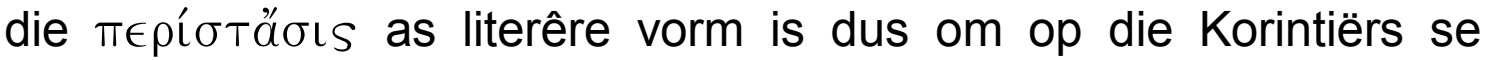
hoogmoed en foutiewe opvatting van wysheid te reageer. Dit hang saam met die vermanings in 4:6 en 4:14.

Die lys beproewings word verskerp in 4:12b-13, waar Paulus die reaksie van apostels op slegte behandeling in drie antiteses beskryf. Hier word die kragtige middel gebruik om die Korintiërs op die gedrag van ware apostels te wys wanneer hulle (soos Christus) sleg behandel word. Dit dien as 'n model wat nagevolg behoort te word (Fee, 1988:181) - 'n tema wat opgeneem word in die volgende gedeelte. In 4:6-13 gebruik Paulus onder andere die volgende retoriese tegnieke om die effek van sy kommunikasie te verhoog:

- Die plasing van tav̂ta aan die begin van 4:6 om die analogieë in $3: 5$ tot 4:5, wat Paulus nou gaan toepas, te beklemtoon (Thiselton, 2000:348).

- jA $\delta \in \lambda \phi o i ́$ in 4:6, wat die besondere verhouding tussen Paulus en die Korintiërs beskryf. 
- Die belangrikste retoriese tegniek in die seksie is die gebruik van kort sinne en asundeton, wat die retoriese vrae in 4:7, die ironie in 4:8a, en die antiteses in 4:10 en 4:12b-13a ondersteun. Vir Demetrius was bondige formulerings en asundeton van die kragtigste ooredingsmiddels (Cronjé, 1993:39).

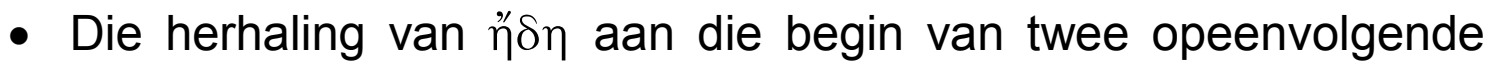
sinsdele in 4:8 dien om die "alreeds" van die Korintiërs se eskatologie as 'n dwaling te beklemtoon. Die tegniek staan bekend as epanaphora (Nida et al., 1983:175).

- Die plasing van $\dot{\eta} \mu \in \hat{\imath} s$... vं $\mu \in \hat{\imath} s \delta$ dé aan die begin van die eerste

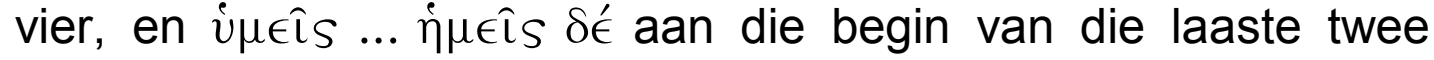
sinsdele in $4: 10$, versterk die antitese tussen die apostels en die Korintiërs. Die drie sinne word ook deur parison gekenmerk.

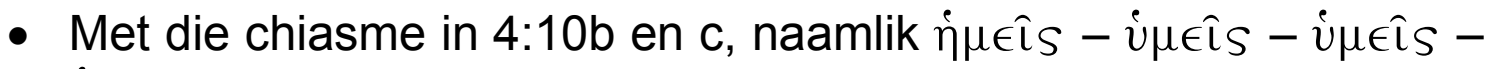

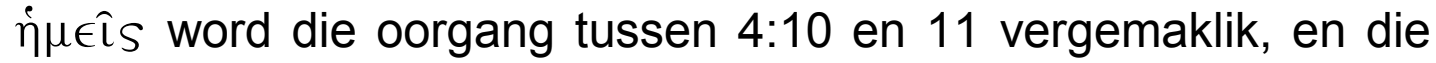
aandag gevestig op dit wat in 4:11-13 oor die apostels gesê gaan word.

- In 4:11-12a word die voegwoord kaıvvyf keer herhaal om werkwoorde aan mekaar te verbind. Die tegniek, bekend as polisundeton, wek die indruk van 'n onbepaalde aantal ontberings wat die apostels moet verduur.

- Parison verhoog ook die impak van die antiteses in 12b-13a.

- Die negatiewe beskouing van die wêreld oor ware apostels in

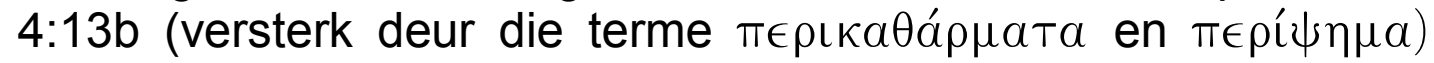
gryp terug na die beeld van 'n skouspel in die arena (4:9b), en wel by wyse van 'n ringskomposisie. Dit rond die beskrywing van die apostels af en as 'n vorm van herhaling, beklemtoon dit hulle situasie.

- Die lys van ontberings in 4:11-13 word ook omraam deur 'n

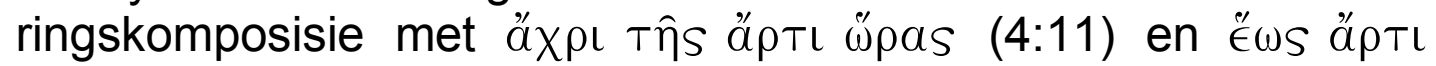
(4:13). Dit dien eweneens om af te rond en die feit te beklemtoon dat al hierdie ontberings op hulle situasie in die huidige bedeling betrekking het.

Om saam te vat: Die retoriese strategie in 4:6-13 kan beskryf word as: "Verduidelik ware apostelskap deur 'n reeks kragtige oorredingsmiddels te gebruik". Twee soorte argumente is geïdentifiseer, naamlik een gebaseer op voorbeeld en die ander op die gesag van 'n Skrifsitaat. Die belangrikste kenmerk van die afdeling is egter die gebruik van retoriese vrae en antiteses, wat albei kragtige oorre- 
dingsmiddels is. Paulus maak ook ruim van ironie gebruik om die eskatologiese dwaling van die Korintiërs te hanteer, asook die beeld van 'n skouspel in die arena om die posisie van die ware apostels te kontrasteer met die gewaande posisie van die Korintiërs. 'n $\Pi \epsilon \rho i ́ \sigma-$ Töoıs aan die einde dien as model van ware apostelskap.

Retoriese tegnieke wat sy kommunikasie ondersteun, sluit in die plasing en/of herhaling van woorde in beklemtoonde posisies, kort formulerings en asundeton, epanaphora, parison, chiasme, polisundeton en twee ringskomposisies.

\subsubsection{Korintiërs 4:14-21: vermaan die Korintiërs as hulle vader}

In hierdie laaste gedeelte gebruik Paulus dieselfde argumente en oorredingsmiddels as in die vorige twee gedeeltes, maar met minder intensiteit wanneer hy afsluit:

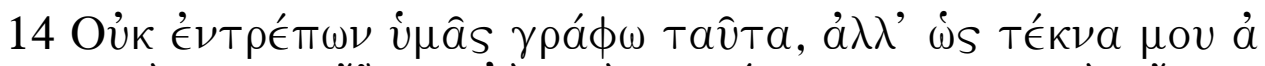

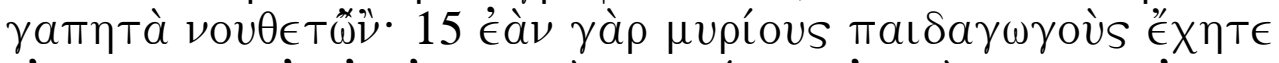

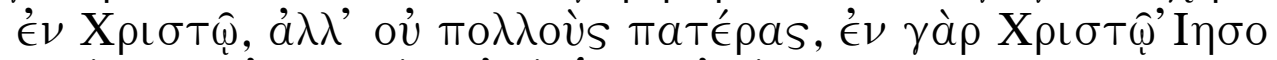

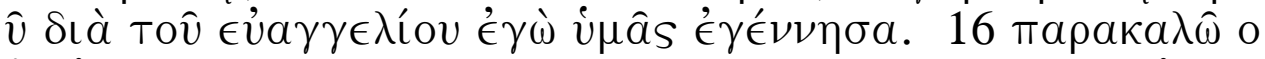

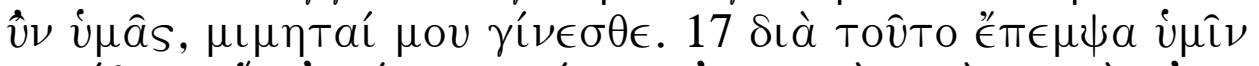

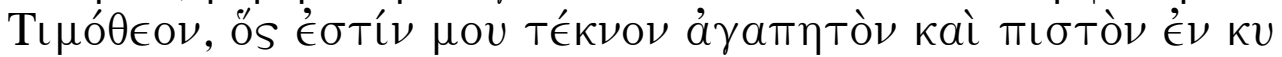

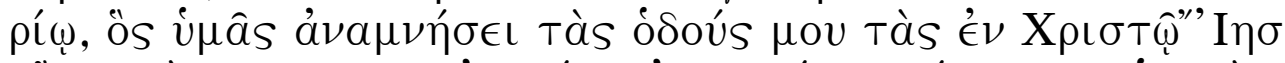

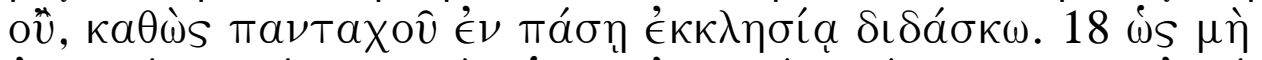

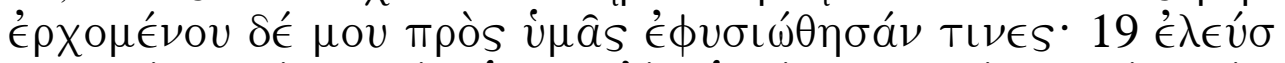

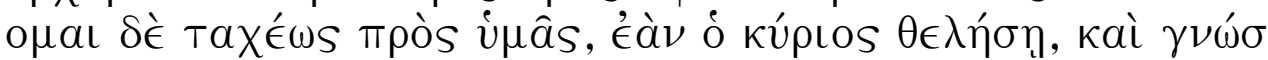

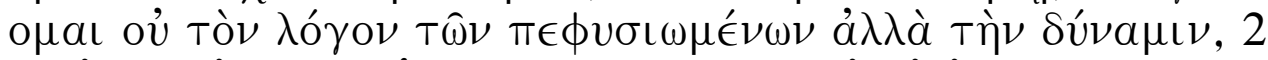

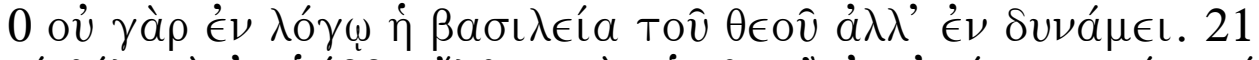

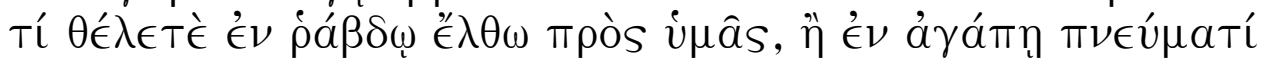
$\tau \in \pi \rho a \hat{T} T \eta T o \dot{s}$.

Die eerste soort argument wat Paulus hier gebruik is weer op analogie gebaseer, dié keer die vader-seunanalogie. Hy het hulle vader

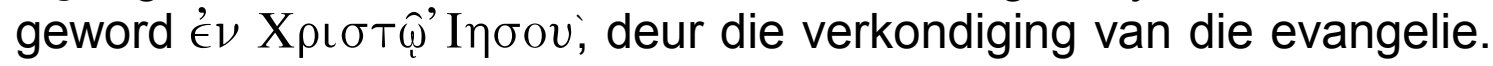
'n Argument gebaseer op analogie is effektief, omdat dit oorspronklik is en die hoorders help om die saak vanuit 'n nuwe perspektief te beskou - soos hierbo aangetoon. Hier is die funksie om die Korintiërs te oorreed om sy outoriteit oor en verantwoordelikheid vir hulle te aanvaar. Anders as Apollos of Petrus, staan hy in 'n unieke verhouding tot hulle: hy is hulle vader en hulle is sy geestelike kinders. Hiermee wil Paulus finaal sy apostoliese gesag bevestig.

'n Tweede soort argument is gebaseer op voorbeeld: die Korintiërs moet sy navolgers word $(4: 16)$. In watter opsig hulle hom moet na-

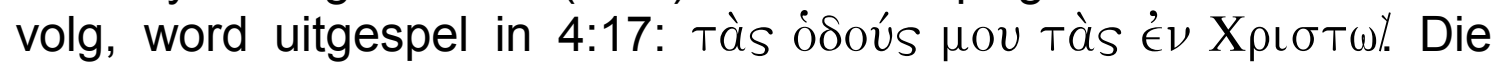


merker $\mathcal{\epsilon} \nu \mathrm{X} \rho\llcorner\sigma \tau \omega /$ is alles-bepalend en emfaties: dit is Paulus se lewenswyse in Christus waaraan Timoteus die Korintiërs moet gaan herinner. Dit is waarom hy Timoteus na hulle toe stuur. Die Korintiërs het sy lewenswyse geken en dit behoort dus vir hulle nie moeilik te gewees het om dit na te volg nie. 'n Argument gebaseer op voorbeeld is juis effektief omdat dit op konkrete wyse 'n abstrakte waarheid illustreer, en so die hoorders help om die saak onder bespreking beter te verstaan. Die feit dat hulle so 'n duidelike voorbeeld gehad het om na te volg, versterk die oorredingskrag van die vermaning.

In 4:19 gebruik Paulus 'n derde soort argument, naamlik een gebaseer op God se betrokkenheid: hy sal gou na hulle kom

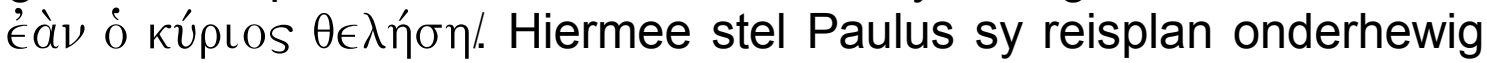
aan die wil van God. Indien die besoek wel plaasvind, is dit nie een wat deur hom of enige mens gewil is nie, maar deur God self. Dan kom hy met God se sanksie - iets wat die Korintiërs deeglik sal moet verreken wanneer hy kom.

Ander oorredingsmiddels in hierdie gedeelte sluit antiteses en twee egte vrae in. Daar kom vier antiteses voor. In 4:14 beskryf hy die doel van sy betoog as 'n vermaning en nie om hulle te beskaam nie. Dit is ' $n$ meer versoenende benadering as in die vorige gedeelte (Conzelmann, 1975:91). Tweedens, kontrasteer hy in 4:15 sy vaderskap met die baie leermeesters, om so sy apostoliese gesag (wat deur die Korintiërs betwyfel is) te bewys. 'n Derde kontras is in 4:18, waar hy die sending van Timoteus teenoor sy eie koms stel om daarmee alle twyfel by die verwaande Korintiërs te besweer dat hy bang is om self na hulle toe te kom omdat hulle pneumatikoi sou wees en hy nie (Wolff, 2000:95). Laastens word die gebruik van woorde in 4:19-20 teenoor die krag van die koninkryk van God gestel - met die klem steeds op die tweede deel van die antitese. Laasgenoemde teenstelling wys, volgens Grosheide (1954:115), terug na die kontras tussen die wysheid van woorde (1:17) en die krag en wysheid van God (1:24), asook tussen die oorredende woorde van menslike wysheid en die betoning van gees en krag. Dit gaan ten diepste oor die teenstelling tussen menslike en goddelike wysheid, waar laasgenoemde in die verkondiging van die kruisevangelie en die effek daarvan bestaan.

Op 'n besondere wyse vat die antiteses in hierdie gedeelte sekere sentrale temas in die eerste vier hoofstukke saam: Paulus se apostoliese gesag, die selfverheffing van die Korintiërs as pneumatikoi, en die evangelia crucis wat as goddelike wysheid teenoor die woorde van menslike wysheid staan, maar wat kragteloos is om te red. 
Hoewel met minder intensiteit as in die vorige gedeelte, het hierdie antiteses dus ook 'n oorredende funksie. Dit is sterker as om die vier hoofstukke bloot saam te vat by wyse van 'n aantal eenduidige stellings.

Die gedeelte word afgesluit met twee vrae. Dit word gevra om inligting te bekom en kan dus nie beskou word as retoriese vrae nie (Cronjé, 1993:41). Met die twee egte vrae in 4:21 wil Paulus van die Korintiërs weet hoe hy na hulle moet kom. Die vrae berus steeds op die vader-kindanalogie waarmee die gedeelte begin het, en die agtergrond is waarskynlik weer die Korintiërs se selfverheffing oor hulle menslike wysheid: laat vaar hulle dit nie, sal hy met die roede moet kom; laat vaar hulle dit, sal hy in die gees van sagmoedigheid kom (Fee, 1988:193-194). Die twee vrae sluit die gedeelte, asook die hele argument oor partydigheid in die eerste vier hoofstukke, op ' $n$ versoenende noot af, maar dit is nie ironies bedoel nie (soos Conzelmann, 1975:93 ten onregte beweer).

Retoriese tegnieke wat die argument in 4:14-21 ondersteun, sluit in:

- Die plasing van $\epsilon \nu \tau \rho \hat{\epsilon} \pi \omega \nu$ aan die begin en $\nu 0 v \theta \in T \omega[\nu]$ aan die einde van 4:14, wat bekend staan as kuklos (Nida et al., 1983: 176). Die funksie daavan is om die twee moontlike redes waarom hy aan hulle skryf, uit te lig.

- Lenski (1963:194), Grosheide (1954:112), Fee (1988:185) en Barrett (1992:115) wys op die huperbole $\mu$ ú́ous maı $\delta a \gamma \omega \gamma$ oùs in 4:15, wat die feit beklemtoon dat die Korintiërs net een vader het, ongeag die hoeveelheid leermeesters wat hulle mag hê.

- Die plasing van Sıà Tov̂To aan die begin van 4:17, vestig die aandag op die rede waarom Paulus vir Timoteus gestuur het. Dit was om die Korintiërs aan Paulus se voorbeeld te herinner, sodat hulle hom kon navolg (Grosheide, 1954:113).

- E $\mathbf{E} \epsilon \hat{\sigma} \sigma o \mu a r$ aan die begin van 4:19 is ook emfaties: die Korintiërs moet weet dat Paulus inderdaad, sekerlik, self sal kom (Lenski, 1963:200).

Saamgevat: Paulus se retoriese strategie in hierdie gedeelte kan beskryf word as: "Vermaan die Korintiërs as hulle vader". In 'n finale poging om hulle te oorreed om hom as apostel te erken en hulle partydigheid te laat vaar, gebruik hy argumente gebaseer op analogie, op voorbeelde, en op God se betrokkenheid. Ander oorredingsmiddels is antiteses, wat sekere sentrale temas in die eerste vier hoof- 
stukke saamvat, asook egte vrae wat op die vader-kindanalogie berus en die gedeelte (asook die eerste vier hoofstukke) op 'n versoenende noot afsluit.

Retoriese tegnieke wat gebruik word sluit in kuklos, die plasing van woorde in beklemtoonde posisies en huperbole.

\section{Gevolgtrekking}

Die doel van die studie was om te bewys dat dit nie nodig is om ' $n$ retoriese model van buite te gebruik, om Paulus se oorredingstrategie in 1 Korintiërs 4 te verstaan nie, mits die teks sistematies deurgewerk word. Die strategie kan uit die teks self gerekonstrueer word en bied ' $n$ sinvolle alternatief op die tradisionele benadering tot retoriese analise. Die sinvolheid is veral daarin geleë dat die teksgesentreerde benadering meer op die funksionele aspekte van die teks fokus terwyl die tradisionele benadering meer op die formele aspekte daarvan fokus.

1 Korintiërs 4 is afgebaken op grond van retoriese oorwegings en in drie gedeeltes verdeel: $4: 1-5 ; 4: 6-13$ en $4: 14-21$. Voorbeelde van verskeie soorte argumente is geïdentifiseer, en kragtige oorredingsmiddels soos antiteses en retoriese vrae is effektief gebruik. ' $n$ Hele reeks erkende retoriese tegnieke het die impak van die kommunikasie verhoog en bygedra om die Korintiërs te oorreed om hulle partydigheid te laat vaar, deur die bediening en die ware aard van apostelskap reg te verstaan.

\section{Geraadpleegde bronne}

ANDERSON, R.D. 1999. Ancient rhetorical theory and Paul. Leuven: Peeters. (CBET 18.)

BARRETT, C.K. 1992. A commentary on the first epistle to the Corinthians. London: Black.

CONZELMANN, H. 1975. 1 Corinthians: a commentary on the first epistle to the Corinthians. Hermeneia: Fortress.

CORNELIUS, E.M. 1998. The effectiveness of 1 Thessalonians: a rhetoricalcritical study. Stellenbosch: University of Stellenbosch. (Ph.D. dissertation.)

CRONJÉ, J.V. 1993. Demetrius on forcible style. Acta patristica et byzantina, 4:33-42.

FEE, G.D. 1988. The first epistle to the Corinthians. Grand Rapids: Eerdmans.

FITZGERALD, J.T. 1988. Cracks in an earthern vessel: an examination of catalogues of hardships in the Corinthian correspondence. Atlanta: Scholars Press. (SBLDS 99.)

GROENEWALD, E.P. 1967. Die eerste brief aan die Korinthiërs. Pretoria: NGKerk Uitgewers. 
GROSHEIDE, F.W. 1954. Commentary on the first epistle to the Corinthians. London: Marshall, Morgan \& Scott.

LENSKI, R.C.H. 1963. The interpretation of St. Paul's first and second epistles to the Corinthians. Minneapolis: Augsburg.

LOUW, J.P. \& NIDA, E. A. 1988. Greek-English Lexicon of the New Testament based on semantic domains. New York: UBS.

MALAN, F.S. 1993. Rhetorical analysis of 1 Cor 4. Theologia viatorum, 20:100114.

MITCHELL, M. 1991. Paul and the rhetoric of reconciliation: an exegetical investigation of the language and composition of 1 Corinthians. Tübingen: Mohr-Siebeck.

NIDA, E.A., LOUW, J.P., SNYMAN, A.H. \& CRONJÉ, J.v.W. 1983. Style and discourse. Goodwood: N.B.P.

POGOLOFF, S.M. 1992. Logos and Sophia: the rhetorical situation of 1 Corinthians. Atlanta: Scholars.

PORTER, S.E. 1997. Paul of Tarsus and his letters. (In Porter, S.E., ed. Handbook of classical rhetoric in the Hellenistic period 330 BC-AD 400. Leiden: Brill. p. 533-585.)

SCHÜSSLER FIORENZA, E. 1987. Rhetorical situation and historical reconstruction in 1 Corinthians. New Testament studies, 33:386-403.

THISELTON, A.C. 2000. The first epistle to the Corinthians: a commentary on the Greek text. Grand Rapids: Eerdmans. (NIGTC.)

TOLMIE, D.F. 2005. Persuading the Galatians: a text-centred rhetorical analysis of a Pauline letter. Tübingen: Mohr-Siebeck. (WUNT 2/90.)

WITHERINGTON, B. 1995. Conflict and community in Corinth: a sociorhetorical commentary on 1 and 2 Corinthians. Grand Rapids: Eerdmans.

WOLFF, C. 2000. Der erste Brief des Paulus an die Korinther. Leipzig: Evangelische Verlagsanstalt. (Theologischer Handkommentar zum Neuen Testament 7.)

\section{Key concepts:}

arguments, types of

Greek-Roman rhetorical system

Pauline literature

rhetorical situation

rhetorical techniques

text-centred approach

\section{Kernbegrippe:}

argumente, tipes

Grieks-Romeinse retoriese sisteem

Pauliniese literatuur

retoriese situasie

retoriese tegnieke

teksgesentreerde benadering 